\title{
BANKING MARKET STRUCTURE, CREATION AND ACTIVITY OF FIRMS: EARLY EVIDENCE FOR COOPERATIVES IN THE ITALIAN CASE
}

\author{
by \\ Francesca GAGLIARDI* ${ }^{*}$ \\ The Business School, University of Hertfordshire, UK
}

Published in Annals of Public and Cooperative Economics, 2009, 80 (4), pp.575-610

\begin{abstract}
This paper investigates whether local differences in banking competition impact on the creation and activity of firms, with a special focus on cooperatives. The empirical analysis, implemented on a sample of Italian firms, reveals non-monotonic effects of bank market power on firm creation and activity. In regard to the former, a bell-shaped relationship is found for both cooperative and non-cooperative firms, suggesting that a moderately concentrated banking market favors firms' creation. A less homogeneous pattern characterizes firms' activity: a bell-shaped parabola is still found for non-cooperative firms, while a U-shaped relationship emerges for cooperatives, showing that active coops benefit from a relatively more intense banking competition.
\end{abstract}

\footnotetext{
* The Business School, University of Hertfordshire, Department of Accounting, Finance and Economics, De Havilland campus, Hatfield, Hertfordshire, AL10 9AB, UK. Tel.: +44 (0)1707 285570; Fax: +44 (0)1707 285455. Email: f.gagliardi@herts.ac.uk.

$\S$ I am grateful to Mariarosaria Agostino, Hulya Dagdeviren, Avinash K. Dixit, Giovanni Dosi, Elena Granaglia, Geoffrey M. Hodgson, Rosanna Nisticò, Douglass C. North, Francesco Trivieri, Ya Ping Yin, and two anonymous referees for their valuable comments and suggestions on earlier versions of this paper. All remaining shortcomings are mine.
} 


\section{INTRODUCTION}

The cooperative firm has been analyzed in the economic literature, on both theoretical and empirical grounds, with respect to a number of different but related issues. Among these, the role of external sources of financing, and especially bank credit, has been regarded a critical factor influencing the creation, functioning and survival of cooperatives (Ben-Ner, 1988a and b). It has been argued that their property rights structure creates a number of issues in the relationship with external financers, due to the problem of guarantees offered to third parties financing the firm (Jossa and Cuomo, 1997). Indeed, workers' typically limited wealth, and consequent risk aversion and liquidity constraints, bound the personal collateral available for obtaining loans (Ben-Ner, 1988a). Moreover, the so-called cooperatives' vaguely defined property rights (Cook, 1995) create a commitment problem of members (Schlicht and von Weizäcker, 1977), which makes agency problems in credit markets more severe for these firms than for other enterprises (Vitaliano, 1983; Drèze, 1993; Dow, 2003). Therefore, although the banking system represents also for other firms an important channel of resources acquisition, it seems reasonable to argue that the structure of the financial sector can have particularly relevant implications for cooperatives.

This work empirically investigates whether, ceteris paribus, the structure of the banking market - an important feature of the institutional environment embedding entrepreneurship - influences differently the financing of cooperatives, as compared to the effects produced for other business types, with regard to both firm creation and entrepreneurial activity. This is not a trivial issue since the economic literature analyzing the effects of bank market power has not provided yet a univocal answer to the question of how competition among banks affects the availability of credit to firms, hence indirectly their formation and functioning. In fact, the structure-conduct-performance (SCP) scheme claims that, as in every other economic sector, lower competition in the banking industry leads to welfare losses (Pagano, 1993; Guzman, 2000). Yet, the studies belonging to the information-based-approach show that, in general terms, the implications of banking market structure can be different from those predicted by the traditional SCP framework, and that the effects on firms' financing, hence on entrepreneurship, are also related to the possibility of setting in and maintaining lending relationships (e.g. Petersen and Rajan, 1995). In light of the above considerations, analyzing the impact of bank market power on firms' financing, hence on entrepreneurship, by distinguishing among different business structures, assumes relev- 
ance since cooperative firms' institutional characteristics may impact on the establishment and/or maintenance of lending relationships.

By discerning among cooperatives and other firms, and between creation and activity, this work enriches the existing literature in several respects. Firstly, it contributes to explore the link between the behavior of banking institutions and cooperative firms' performance, which is a highly disputed issue. Indeed, although the difficulties that cooperators might face in obtaining and providing financial capital have been used as an argument against the viability of these firms (Blair et al, 2000), research on cooperatives suggests that their success is highly dependent on the type of financial and cultural regime prevailing in the local and national economy (Hovart, 1975; Thomas and Defourny, 1990; Gagliardi, 2009). Secondly, although other contributions studied the effects of bank competition on entrepreneurship (e.g. Black and Strahan, 2002; Bonaccorsi Di Patti and Dell'Ariccia, 2004), they have not accounted for the possibility that the impact of differences in credit market structure on firms' financing may vary among different business types.

The present paper, and this is its third distinctive feature, aims to evaluate the results of the econometric investigation by means of the institutional complementarity approach, a novel interpretative framework recently proposed in the institutionalist literature. In perhaps the most extensive treatment so far existing on this issue, Aoki (2001) claims that the relationships among the characteristics of various market governance mechanisms prevailing in one economy, at any particular point in time, may be complementary in the sense that the effectiveness (or the presence) of one governance mechanism can be reinforced - either directly or indirectly - by the presence of a particular arrangement in the same or embedding domain. So that, in terms of the concept à la Aoki (2001), this work intends to assess whether the institutional counterpart complementary to the creation and activity of different business structures is a local banking market characterized by a higher or lower degree of competition.

To carry out the investigation the research uses data on firms operating in 27 industries in the 103 Italian provinces during the period 1998-2003. The administrative province is the relevant local market in the Italian case and, since the structure of the banking industry differs substantially across local markets, this provides sufficient cross-sectional variability within a single institutional framework. So that, given this regulatory uniformity, there is no need to control for different regimes (Bonaccorsi di Patti et 
al, 2004). Building upon several other studies on competition in the banking industry, bank market power is measured by using the Herfindahl-Hirschman Index on deposits. Two models are then estimated: one for firm birth, the other for firm activity.

The remainder of the paper is organized as follows: Section 2 presents a review of the major literature on the economic effects of bank competition, as well as a brief overview of the issues related to the financing of cooperative firms; Section 3 illustrates the econometric specifications and methodology adopted; Section 4 describes the data; Section 5 comments on the results obtained and the robustness checks performed; finally, Section 6 concludes.

\section{BANKING MARKET STRUCTURE AND ENTREPRENEURSHIP: A BRIEF LITERATURE REVIEW}

In recent years newly created firms received considerable attention in the economic literature, especially as regards small and medium sized ones. It has indeed been argued that since a significant proportion of employment is created by new firms, which often bring productive innovation, it is essential to understand the factors promoting or mitigating entrepreneurial activity (Lee et al, 2004).

A first line of research focuses on the personal characteristics of entrepreneurs (e.g. Blanchflower and Oswald, 1990; Chell et al, 1991), whereas a second line of study explains firm start-up and activity focusing on environmental and institutional characteristics. In this latter strand of analysis capital availability has been considered an important issue. In fact, since entrepreneurship may be limited by liquidity constraints (Evans and Jovanovic, 1989), the financial resources that potential entrepreneurs have to finance their business are expected to influence firm creation and activity. However, while numerous studies have shown that entrepreneurship is bounded by liquidity constraints (e.g. Storey, 1982; Garofoli, 1994; Keeble and Walker, 1994, Fotopoulos and Spence, 1999; Guiso et al, 2004a), fewer works investigated how, by influencing credit availability, the structure of the financial sector affects entrepreneurial activity (Black et al, 2002). This issue forms part of the wider debate on the economic effects of bank competition that has lately attracted the attention of many scholars. The conclusions so far reached in this dispute are not univocal, on both theoretical and empirical grounds.

The conventional structure-conduct-performance (SCP) scheme argues that restraining competition in the banking industry produces welfare losses, since banks enjoying market power can lower the 
amount of credit granted and charge higher interest rates on loans (e.g. Pagano, 1993; Guzman, 2000; Cetorelli, 2001). Among the studies providing empirical support to this approach, Black et al. (2002) show that the late 1970s U.S. branching and interstate banking reform, which fostered competition in the credit sector by removing restrictions on branching, has been beneficial to entrepreneurship. Indeed, the rate of new incorporations in local markets increased significantly when states opened to external competition. In line with this conclusion also Strahan (2002) and Cetorelli (2004) document a positive link between bank competition and entrepreneurship.

The Black and Strahan (2002) model has been questioned by Wall (2004) who shows that, when the effects of U.S. deregulation are allowed to differ across regions, entrepreneurship is inversely related to increased banking competition in some regions, and positively associated in others. Recent studies proposed within the information-based-approach raise doubts on the beneficial impact of bank competition on the economy. Broadly speaking, these contributions emphasize the role of asymmetric information problems in lending relationships and show that, by favoring the set in of lending relationships, market power in banking allows firms to obtain better financing terms.

Within the information-based-approach, Petersen and Rajan (1995) prove that younger firms may receive more credit, and at better rates, in markets where banks hold a relatively high market power. The reason for this is that, although unknown young firms should face higher cost of credit and receive lower amount of loans - as a result of being riskier borrowers - banks enjoying market power may adopt the following lending strategy to young businesses: they may initially charge lower loan interest rates in order to establish a lending relationship, and then extract rent (by charging higher interest rates) from eventually successful firms. Basically, in adopting such a strategy banks count on maintaining lending relationships in the future. However, this is less likely to occur where firms can be driven out by competitors, so that in more competitive credit markets banks have less incentives to bear the initial cost of lending at lower rates to riskier borrowers, with the result that the latter could actually receive less credit and at higher rates. Nonetheless, Boot and Thakor (2000, p. 708) argue that "(i) there is more transaction lending at lower levels of interbank competition than at higher levels; (ii) increased interbank competition will increase relationship lending, but each loan will have less added value for borrowers". 
In support to the information-based-approach, Bonaccorsi di Patti and Dell'Ariccia (2004) find that bank market power is beneficial to firm birth only up to a certain point, after which it exerts a negative impact. Zarutskie (2006) traces the firm-level effects of the Riegle-Neal Interstate Banking and Branching Efficiency Act of 1994, a major U.S. banking market deregulation which increased competition in credit markets. The author finds that, by increasing financial constraints, the deregulation had an adverse effect on the entrepreneurial activity of newly formed businesses. Shaffer (1998) shows that funds' allocative efficiency is negatively influenced by increased banking competition. This is because the probability that low-quality applicants receive credit is higher as the number of banks in the market increases, when banks' screening models are imperfect and banks cannot distinguish new borrowers from those who have already been turned down by other banks. In line with this result is the work by Cao and Shi (2001), claiming that credit quantities are smaller and loan rates higher in markets where there are many competing banks, as competition would reduce the number of banks performing screening and competing in credit supply. Moreover, Marquez (2002) proves that borrower-specific information becomes more disperse in more competitive credit markets - since each bank has information on a smaller pool of borrowers - leading to less efficient screening and higher interest rates.

Yet, beside the abovementioned studies, other works reach different conclusions. Indeed, Chen (2007) finds that increased banking competition improved loans quality in EU-15 countries, after the Second European Banking Directive has been introduced. Bertrand et al. (2007) document that, in the French case, following the deregulation process started in 1985 - which promoted, among other things, a more vigorous banking competition - banks improved their monitoring and/or screening functions and this had a positive effect on entrepreneurship. Moreover, Benfratello et al. (2006) argue that higher competition can lead banks to introduce better practices in screening, selecting, evaluating and monitoring firms since, as Chen (2005) claims, when banks face competitive pressures, they are more likely to choose screening activity instead of collateral requirements.

In between the two lines of research above discussed, other studies claim that market power in banking may have both positive and negative effects on the economy, making it difficult to establish which one predominates (e.g. Cetorelli, 1997; Cetorelli and Peretto, 2000). This result is supported empirically by works as Cetorelli and Strahan (2006), finding that, depending on the degree of bank competition, 
some firms benefit while others lose. Also, Cetorelli (2003) shows that increased banking competition influences industries' life-cycle dynamics by promoting job creation and growth at the start-up phase and in the early stages of entry. Yet, banking competition accelerates the exit of more mature establishments.

The studies surveyed indicate unsettlement in both the theoretical and empirical literature as to the impact of banking market structure on entrepreneurs' access to credit, hence, on entrepreneurial activity. This calls for further research and the present paper aims to bring a new contribution on the topic by looking at the effects that differences in the structure of local credit markets can exert on the creation and activity of cooperative and non-cooperative firms.

\subsection{Cooperative firms' financing and performance. Does the institutional context matter?}

Distinguishing firms according to their institutional form is a non-trivial issue, since the availability of external sources of financing, and especially bank credit, has been regarded a critical factor influencing the creation, functioning and survival of cooperatives (Ben-Ner, 1988a and b). Indeed, $t$ is widely accepted by scholars that since internal financing is neither sustainable nor efficient, due to the bias toward short-term investment and/or underinvestment created by the horizon problem ${ }^{1}$ (Furubotn and Pejovich, 1970), external financing is the main channel of resources acquisition for cooperatives (Mygind, 1990). Vanek (1975), for instance, points out that, to avoid the problem created by self-financing, a cooperative economy needs a banking system providing the required funds. However, it has been argued that the institutional characteristics of cooperative firms create a number of issues in the relationship with external financers. By leading to agency problems in credit markets, cooperatives' vaguely defined property rights (Cook, 1995) imply that these firms are likely to face higher costs of capital and/or credit rationing (Vitaliano, 1983; Drèze, 1993; Dow, 2003) and this limits their extension in market economies (Enberg, 1993).

More in detail, a first problem arises from workers' typically limited wealth, and consequent risk aversion and liquidity constraints, which - by bounding the personal collateral available for obtaining loans - create a problem in terms of guarantees offered to third parties financing the firm (Jossa and Cu-

\footnotetext{
${ }^{1}$ The horizon problem concerns the impossibility for partners to recoup the self-financed capital invested in the firm when their expected tenure in the firm is shorter than the time it takes for the stream of discounted net returns from the project to equal the initial cost of the investment.
} 
omo, 1997). This can constrain the amount of debt that can be raised and increase the cost of borrowing (Ben-Ner, 1988a). According to Putterman (1993), workers' limited wealth, and the high cost to them of not diversifying risk, ${ }^{2}$ explain why cooperative firms are relatively rare as an organizational form.

A further issue that contributes to render the bank-firm link more complex for cooperatives than for other business structures is the so-called commitment problem of members. Schlicht and von Weizäcker (1977) argue that in its essence, the commitment problem - which in their view is the root of the financing problems faced by cooperatives - arises from the fact that cooperative members are more likely than the partners of a capitalist firm to leave the company if its profitability deteriorates. So that, they may lack effort to operate successfully if in risky situations substantial parts of the losses can be get rid off by bankruptcy. From the bank's viewpoint, this implies that lending to a firm of yet unknown future profitability may be riskier in the case of a cooperative firm, since decisions tend to be short-sighted.

An additional impediment to the financing of cooperatives, hence to their creation and development, results from the increased establishment costs created by their relative rarity as an organizational form (Ben-Ner, 1988b). These higher costs arise from two main factors: firstly, the issues previously discussed imply that acquisition of information about coops on the part of financial intermediaries is costlier than information on capitalist firms; secondly, since financial expertise on cooperatives is relatively more scarce and expensive, potential lenders may restrict loans and/or require higher interest rates for funding firms with unknown track records (Jefferis and Mason, 1990). In other words, "capital may be more costly [or less available] for cooperatives than for other firms because, being an unfamiliar type of organization, they may be perceived as riskier organizations than capitalist firms" (Ben-Ner, 1998a, p. 290). ${ }^{3}$

Finally, cooperatives are not profit-oriented and, for financial intermediaries, this poses the problem of how to evaluate the performance of these firms. Conventional economic indicators of performance

\footnotetext{
${ }^{2}$ Cooperative members cannot diversify the risk to their employment, human capital and financial capital which are bundled in the same coop (Ben-Ner, 1988b).

${ }^{3}$ On the issue of cooperatives' credit riskiness, Jefferis and Mason (1990) argue that it is important to distinguish between actual and perceived risk. Indeed, unfamiliarity with coops on the part of banks causes an information deficiency, which results in a higher level of risk being perceived by the lender, hence in either a higher interest rate on loans or a restriction on funds. However, this does not necessarily mean that the actual risk is greater, since the crucial factor is the risk perceived on the basis of the available information.
} 
and efficiency provide an incomplete basis for comparing cooperative and capitalist firms, since these enterprises tend to operate under, at least partially, different sets of objectives (Bartlett et al. 1992). It can be argued that the major discriminant between cooperative and capitalist firms lies in the role ascribed to capital. In the former capital is an instrument necessary to realize the ultimate aim of those who decide to join a cooperative, be this the satisfaction of a need, the procurement of a job, and so on. By contrast, in the latter capital is both instrument and ultimate aim. In other words, beside economic purposes, cooperatives also pursue social goals; therefore, the role of relational goods - often able to counterbalance free riding and promote economic performance - should not be neglected (Zamagni 2005). However, how to account for them when assessing potential loans remains an issue.

The difficulties that cooperators might face in obtaining and providing financial capital have been used as an argument against the viability of these firms (Blair et al, 2000). However, research on cooperatives suggests that their success is highly dependent on the type of financial and cultural regime that prevails in the local and national economy (Milenkovitch, 1971; Hovart, 1975; Thomas and Logan, 1982; Thomas and Defourny, 1990; Gagliardi, 2009). There is, in fact, substantial evidence showing that limited access to finance and/or inappropriate financing mechanisms imply that cooperatives have less impact than they could have (Thomas and Defourny, 1990). Jefferis and Mason (1990) point out that one reason for the decline of the British cooperative sector is that the financial environment has been restrictive on coops' ability to raise finance (see also Oakeshott, 1978; Logan and Gregory, 1981). An exception to this general attitude on the part of financial institutions occurred in the decade from 1976 to 1986, when there was a substantially increased availability of finance from public sources, which contributed to the massive expansion of the British cooperative sector between 1980 and 1986 (Estrin and Pérotin, 1987; Jefferis and Mason, 1990). ${ }^{4}$

Several studies have shown that finance does not represent a particular problem for cooperatives when institutional conditions are such that banks develop experience in lending to the cooperative sec-

\footnotetext{
${ }^{4}$ Podivinsky and Stewart (2007) report that cooperative firms' registrations increased by more than $13 \%$ over the 10 year period 1976-1985. Moreover, looking at the general pattern of entry in the UK, a comparison of the first half of the period (1976-1980) with the second one (1981-1985) reveals a growth rate of more than $300 \%$ in VAT registrations for cooperatives and of $11 \%$ for other firms.
} 
tor, as this tends to favor the acquisition of information on cooperatives' credit riskiness (Bonin et al, 1993; Smith, 2001). Analyzing the historical concentration of cooperative and capitalist firms, Ben-Ner (1988b) concludes that cooperatives' diffusion (in labour and skill intensive industries) has been positively affected by mainly two factors, which reduced their formation costs: easier credit availability on more competitive and less discriminatory capital markets, and access to capital through specialized banks supported by the State or cooperatives' organisations. In the Basque region of Spain, for instance, where Mondragón cooperatives are based, the availability of a specialized source of finance, through the interventionist role of the Caja Laboral Popular bank, has been a major factor accounting for the success of these Spanish coops (Fairclough, 1987). Indeed, at an early stage in their history, the Caja bank was set up with the explicit purpose of providing external funds to cooperative firms (Thomas and Logan, 1982).

\section{EMPIRICAL QUESTION AND METHODOLOGY}

This work empirically assesses the relationship between bank market power and the creation and activity of Italian firms, with a special focus on cooperatives. The central hypothesis of the paper is that, ceteris paribus, local differences in the structure of the banking market influence differently the financing of cooperatives, as compared to other forms of business organizations (namely, partnerships and corporations - henceforth, non-cooperative firms), with regard to both firm creation and entrepreneurial activity.

The reasoning set out in the previous section provides the justification for carrying out the analysis by distinguishing between cooperative and non-cooperative firms. On one hand, it is reasonable to argue that, other things held equal, at an informative level cooperatives represent the least transparent (or more opaque) category of firms, hence (potentially) the riskiest business type for financial intermediaries. On the other hand, the studies belonging to the information-based-approach show that, in general terms, the implications of banking market structure can be different from those predicted by the traditional structure-conduct-performance scheme, with the effects on firms' financing, hence on entrepreneurship, being also related to the possibility of setting in and maintaining lending relationships. In light of these considerations, focusing on possible differences among business structures assumes relevance since cooperative firms' institutional characteristics may impact negatively on the establishment and/or mainten- 
ance of lending relationships. The empirical strategy employed to carry out the analysis is presented in the following sub-sections.

\subsection{Measuring firm birth and activity}

Firms' annual birth rate in industry $i$, province $p$ and year $t$ is measured as the flow of newly registered firms in year $t$ on the stock of firms registered at the end of year $t-1$ :

birth $_{i p t}=\frac{\text { newreg }_{\text {ipt }}}{\text { reg }_{\text {ipt }-1}}$, where $i=1, \ldots, 27 ; p=1, \ldots, 103 ; t=1998, \ldots, 2003$.

As far as firms' activity rate is concerned, this is given, for each province $p$ and sector $i$, by the flow of active firms in year $t$ divided by the stock of firms registered at the end of the same year:

activity $_{i p t}=\frac{\text { active }_{i p t}}{\text { reg }_{\text {ipt }}}$, where $i=1, \ldots, 27 ; p=1, \ldots, 103 ; t=1998, \ldots, 2003$.

The activity rate is here interpreted as a rough measure of firms' 'good health', since - as indicated by InfoCamere $e^{5}$ the stock of firms registered at the end of each year includes, beside the active ones, also those inactive, suspended, in liquidation and bankrupted. Thus, the activity rate gives the proportion of firms which are at least not in a declared state of difficulty.

The distribution of firms' birth and activity rates is such that the former variable takes on the value of zero for a considerable range of observations in both samples (i.e. cooperative and non-cooperative firms), whereas the latter assumes zero values for a non-trivial proportion of data only in the case of cooperatives. Given these features of the dependent variables, the Tobit technique represents the most suitable econometric modeling choice, as it allows to deal with continuous variables having positive probability mass point at zero. Yet, as argued by Wooldridge (2002), applying a Tobit model to a panel data structure entails some problems. Firstly, one of the main assumptions underlying the unobserved effects (both random and fixed) Tobit model is the strict exogeneity of regressors. However, as argued in Section 5, there is reason to suspect that the indicator of bank market power may be endogenous. Secondly, a fixed

\footnotetext{
${ }^{5}$ InfoCamere is the source from which data on firms' demographics have been obtained. This organization coordinates, at national level, the network of provincial Chambers of Commerce.
} 
effects Tobit model would bring about - as the main doctrine argues - a further shortcoming, since estimating limited dependent variable models with fixed effects entails an incidental parameters problem, which leads to inconsistent estimation of $\boldsymbol{\beta}$ with $T$ fixed and $N \rightarrow \infty$ (Wooldridge 2002).

To avoid the abovementioned drawbacks, estimations are carried out on firms' average birth and activity rates. These are computed - for each province - at industry level on the years 1999-2003, since some of the market level variables used are measured at the beginning of the period under analysis (see sub-section 3.3). ${ }^{6}$ Employing average values brings about two further advantages: it allows to smooth the effect of temporary shocks, and leaves the opportunity to include in the analysis both industryspecific effects and the heterogeneity across markets.

\subsection{Measuring bank market power}

Bank market power is measured at provincial level by using the Herfindahl-Hirschman Index (HHI) on deposits. ${ }^{7}$ Since in Italy (as in most European countries) data at local banking office level are not publicly available, by following Carbò Valverde et al. (2003), and Agostino and Trivieri (2008), each variable $x$ needed in the computation of the HHI indicator is drawn as:

$$
d_{i p t}=D_{i t} *\left(\frac{B R_{i p t}}{B R_{i t}}\right)
$$

where $i=1, \ldots, N ; p=1, \ldots, 103 ; t=1998, \ldots, 2003 ; d_{i p t}$ indicates deposits for each branch office of bank $i$ in province $p$ in year $t ; D_{i t}$ is the balance sheet value of deposits for bank $i$ in year $t ; B R_{i p t}$ is the number of branch offices of bank $i$ in province $p$ in year $t$; finally, $B R_{i t}$ is the total number of branch offices of bank $i$ in year $t$. Then, for each year considered in the analysis, the indicator of local banking concentration is computed as:

$$
H H I_{p}=\sum\left(m s_{i p}\right)^{2},
$$

\footnotetext{
${ }^{6}$ Using variables defined in a period preceding the one considered in the empirical investigation underlies the assumption that some provincial characteristics take time to display their impact on firm's creation and activity.

${ }^{7}$ The HHI is computed on deposits (and not on loans) since depositors typically have less market power than borrowers.
} 
where $m s_{i p}=\left(\frac{d_{i p}}{D_{p}}\right)$ is the market share on deposits for each branch office of bank $i$ in province $p$, and $D_{p}=\sum_{i} D_{i p}$

In the structure-conduct-performance paradigm, the HHI index is viewed as an inverse measure of bank competition: higher values of $\mathrm{HHI}$ are associated with a higher concentration of the credit market, hence with lower competition. Conversely, lower values of HHI indicate a less concentrated banking industry, and thus more competition. ${ }^{8}$

\subsection{The econometric specifications}

As previously mentioned, the empirical analysis is implemented by applying the Tobit technique to estimate the models for the creation and activity of cooperatives, and also for the creation of noncooperative firms. Linear regressions are, instead, carried out when the average activity rate is the dependent variable in the equation estimated for the sample of non-cooperative firms (see sub-section 3.1).

In the econometric specification of the model concerning firm birth (BIRTH) ${ }^{9}$ the following explanatory variables are included: the 1999-2003 firms' average cancellation rate (DEATH) ${ }^{10}$ which should be positively correlated to firm birth since, due to firms' turnover, relatively more firms should be created where a larger proportion of existing firms disappear ${ }^{11}$; the initial industry share in each province (INDUSHARE), accounting for the fact that new firms are less likely to be formed in relatively densely

\footnotetext{
${ }^{8}$ The Herfindahl-Hirschman Index is the measure used in most studies on banking market power, though it has been criticised by several authors (for a critical review see Guzman, 2000). Alternative indicators suggested by the literature are the Lerner Index and the non-structural $H$ statistic of Panzar and Rosse (1987). However, data availability has precluded the use of such indicators in the empirical analysis of this paper.

${ }^{9}$ This variable is labeled BIRTH_OF for non-cooperative firms and BIRTH_COOP when referred to cooperatives.

${ }^{10}$ DEATH is obtained by averaging over the years 1999-2003 the annual cancellation rates, computed for sector $i$ and province $p$ as the ratio of firms cancelled in year $t$ over the stock of firms registered at the end of year $t-1$. This variable is labeled similarly to BIRTH, depending on which group of firms it refers to.

${ }^{11}$ The regressions having BIRTH_COOP as dependent variable include also the birth and death rates of other firms (BIRTH_OF and DEATH_OF).
} 
populated markets ${ }^{12}$; the indicator of local banking concentration (HHI), described in sub-section 3.2; the (log of) average provincial population (POP), as a measure of local market size; the share of workforce with a high school diploma or higher degree in 1997 (EDUC), proxying for human capital endowment; a proxy for the strength of community ties (STIES) - or, as some authors claim, a proxy for civicness, hence for social capital ${ }^{13}$ - obtained by averaging data on electoral participation, ${ }^{14}$ so as to account for the possible impact of differences in social structure on firm birth; a proxy for adherence to corporate law, given by the crimes committed against the economy normalized by population and averaged over the years 1999-2003 (CRIMEECO) ${ }^{15}$; a dummy variable (CEN-NORTH), taking on the value of 1 for Center Northern provinces and 0 otherwise; the share of municipalities having less than 30,000 residents in 1996 (SMALLTOWN), accounting for the presence of external and agglomeration economies which should lead urban areas to have higher firm birth rates; a proxy for the level of local infrastructures (ROADS), measured as kilometers of non-urban roads at the end of 1996 normalized by province area, and expected to have a positive effect on economic activity, hence on entrepreneurship; the provincial real per capita income in 1998 (RPI) as a proxy for local wealth controlling for the fact that, if convergence effects are at work, economies with low initial incomes should grow faster (Barro, 1991;

\footnotetext{
${ }^{12}$ INDUSHARE is calculated as the ratio of registered firms in industry $i$ and province $p$ in 1998 over the total number of firms registered in province $p$ in the same year.

${ }^{13}$ Starting from Putnam's (1993) seminal study, various indexes proxying for social capital have been used in the literature. It is, however, still debated which is the most appropriate indicator. The electoral participation to referenda and elections has been used by studies as Helliwell and Putnam (1995), Forni and Paba (2000), Guiso et al. (2004a,
} 2004b) and Benfratello et al. (2006).

${ }^{14}$ The rounds of voting included in STIES are: the 1995 referenda, the 1999 European elections and the 2001 referenda. The choice of these rounds has been driven by data availability. Indeed, information on participation to the general elections is not available at provincial level, but only for constituencies. Moreover, regional elections do not always take place for all regions in the same year, so that data on voters turnout are not evenly available.

${ }^{15}$ The crimes this variable includes are: falsity in acts and persons; counterfeit, alteration or use of trademarks; other crimes against the safety, the economy and the public trust. Since information on this variable was accessible only for the years 2000-2003, the 2000 figures have been imputed to the year 1999, so as to compute the mean value over the period 1999-2003. 
Mankiw et al, 1992), hence should display higher rates of firm creation; finally, to account for sectoral specific effects, industry dummies are included (INDUSTRY).

Turning to the specification for the regressions on firms' activity rate (ACTV), ${ }^{16}$ beside the variables so far described, it accounts also for firms' average birth rates. Moreover, in the equation estimated for cooperatives, the average activity rate of other firms (ACTV_OF) is also employed. ${ }^{17}$ For a more detailed description of the variables included in the empirical models and for their main summary statistics see tables 1 and 2 , respectively. ${ }^{18}$

[Insert tables 1 and 2 here]

\section{DATA}

The data used in this study come from several sources. Information on firms has been obtained from Movimprese, a database compiled by InfoCamere containing data on firms' demographics collected from local firm registries. In particular, gross flows of newly created, active and cancelled firms are present in this dataset, as well as end of year stocks of registered firms. This piece of information is available for 103 provinces, 28 industrial sectors and firm legal structure (i.e. sole traders, partnerships, corporations, cooperatives, and other legal forms). The dataset for the period 1998-2003 is initially made up of 17,304 observations. From it, are dropped observations on firms operating in the financial sector, since the great part of financial firms are banks. This leads to 16,686 observations. Then, since the intention is to focus on enterprises, sole traders are excluded. The category labeled 'other firms' is also deleted because it groups a heterogeneous class, comprising a great number of typologies, in many cases representative of only a small number of firms. Finally, after taking the average values for the period

\footnotetext{
${ }^{16}$ Also this variable is labeled differently depending on which group of firms is taken into account. It is identified as ACTV_COOP in the estimations for cooperatives and as ACTV_OF in those carried out on non-cooperative firms.

${ }^{17}$ Data availability precluded the possibility to explicitly account for other non-financial variables that may impact on firms' activity. Nonetheless, both industry and market specific effects can be included in the empirical models to mitigate the concern for omitted variables (see sub-section 5.1). Yet, the intention for future research is to dispose of a more varied and richer dataset.

${ }^{18}$ The correlation matrix for the variables used in the estimations is reported in the Appendix.
} 
1999-2003, and checking for the presence of outliers, the sample employed in the estimations is made up of 2,220 observations. ${ }^{19}$

A second dataset employed is BILBANK, edited by the Italian Banking Association (ABI) and containing balance sheet data on nearly all Italian banks for each year in the period 1998-2003. A third piece of information comes from the Bank of Italy and regards the provincial distribution of branches for each Italian bank over the period 1998-2003. This is used to disaggregate banking balance sheet data at provincial level, as illustrated in sub-section 3.2. A fourth data source is the Italian National Statistical Institute (ISTAT): figures on provincial income, population, voters' turnout, and crimes against the economy are drawn from here. Finally, data on human capital, municipal distribution of population and infrastructural endowment are drawn from the Bonaccorsi di Patti and Dell'Ariccia (2004) database.

Table 2 reports the main summary statistics for the sample employed in the estimations. As shown there, non-cooperative firms' average birth rate is $2.17 \%$. This rate is highest $(25 \%)$ in fishery, and in the leather tanning and finishing industry, while its lowest (positive) value is in (other) public, social and personal services $(0.09 \%)$. Passing to cooperatives, table 2 reports that their average birth rate is $2.06 \%$. This is maximum (50\%) in transports, storage and communications, and in the manufacture of mechanical machinery and equipment. Yet, fewest coops are formed in agriculture, hunting and forestry $(0.06 \%)$.

As far as firms' average activity rate is concerned, this is $78.17 \%$ for non-cooperative firms (see table $2)$, and it is maximum (100\%) in the sectors of: fishery; mineral extraction; chemical production; manufacture of transport means; electricity, water and gas production and distribution, and education. In all the just mentioned sectors but fishery, also cooperative firms have the highest activity rate $(100 \%)-$ on average equal to $66.02 \%$ (see table 2) - as well as in the remaining manufacturing industries, the hospitality and restoration sector, the transports, storage and communications industry, and the health and social services sector. On the other hand, firms' lowest (positive) activity rates are in chemicals production for non-cooperative firms (22.56\%), and in constructions for cooperatives (7.54\%).

It is worth noting that the average cancellation rate is maximum in the fishery sector for noncooperative firms $(15 \%)$, and for cooperatives in the non-energy minerals extractive industry, in some

\footnotetext{
${ }^{19}$ Following Servèn (2003), the criterion used to operate the outliers correction is to consider as outliers the observations for which any of the variables lie beyond 10 standard deviation away from the mean.
} 
manufacturing sectors, and in electricity, water and gas production and distribution (50\%). Moreover, the minimum (positive) rate of cancellation is in the transports, storage and communication industry for non-cooperative firms $(0.26 \%)$, and in the construction industry for cooperatives $(0.63 \%)$.

Regarding territorial differences in entrepreneurship, in the sample, the average birth rate of noncooperative firms is $2.44 \%$ in the Center-Northern area, and $1.69 \%$ in the Southern one. For cooperatives, instead, these figures are $2.45 \%$ and $1.40 \%$, respectively. Also firms' activity rate is higher in the CenterNorth than in the South $(79.89 \%$ versus $75.19 \%$ for non-cooperatives, and $67.63 \%$ versus $63.24 \%$ for cooperatives). Finally, with respect to firms' cancellation, this is higher in the Center-North than in the South, for both non-cooperative (2.98\% versus $2.34 \%$ ) and cooperative firms (3.61\% versus $2.37 \%)$.

\section{RESULTS}

Estimation results are reported in tables 3-6. All estimations have been carried out using robust standard errors. ${ }^{20}$ After having run all regressions, the average value of the square of HHI (HHI2) has been included in the econometric specifications, in order to test for non-monotonic effects of local banking concentration on firm creation and activity. Results obtained from these latter estimations reveal statistically significant non-linear effects of bank market power for both samples. This suggests that the specifications with non-linearity are the relevant ones. Yet, a major criticism that could be advanced to the analysis is that the indicator of local banking concentration may be endogenous, if banks tend to enter local markets where the rates of firm creation and activity are higher for exogenous reasons. To deal with this potential objection all regressions are re-estimated by testing for endogeneity. To do so, the

\footnotetext{
${ }^{20}$ A way to compute robust standard errors for the Tobit model is to resort to interval regression. To do so, it is first necessary to reconfigure the data by assigning two values of the response variable to each observation. When the response variable is left-censored, as in the case under exam, the first value is set to missing and the other to zero. Of course, the point estimates obtained with the interval regression are exactly the same as those of the Tobit regression. Therefore, to avoid cluttering, only the interval regression estimates are reported.
} 
Wald test is carried out for the Tobit regressions and the Hausman test is run for the OLS regressions. ${ }^{21}$ Regarding the instruments employed, these are the HHI indicator and DENSITY (provincial population over province area), both taken at their 1995 values, and MUN (number of provincial municipalities in logarithmic terms). ${ }^{22}$

The estimations carried out on the sample of cooperative firms do not reveal presence of endogeneity of HHI and HHI2 for both BIRTH_COOP and ACTV_COOP (see table 3). Therefore, the results previously obtained, and reported in table 3, are the relevant ones for these models. Focusing on the variable of interest, that is the measure of bank market power, column BIRTH_COOP in table 3 shows that HHI follows a bell-shaped pattern; this suggests that a relatively concentrated local credit market is beneficial to the creation of cooperative firms, while it has a detrimental impact after it reaches a threshold. Looking at the results on the quadratic functional form of HHI in the estimates for the model on firm's activity (column ACTV_COOP in table 3), the evidence shows a U-shaped relationship between bank market power and cooperatives' activity rate. This indicates that active cooperatives benefit from more intense banking competition, even though this latter has negative effects when too exasperated.

\section{[Insert table 3 here]}

Turning to the results obtained for the sample of non-cooperative firms, presented in table 4 , the Wald test reported in column BIRTH_OF fails to reject the null hypothesis of exogeneity of the concentration indicator in the model for birth. Figures in the same table show that, as for BIRTH_COOP, also in the case of BIRTH_OF the relationship between non-cooperative firms' creation and bank market power presents a bell-shaped pattern. As regards the model for firm activity, the Hausman test reveals evidence of endogeneity of HHI and HHI2 (table 4, column ACTV_OF). As opposed to the evidence obtained for

\footnotetext{
${ }^{21}$ The Wald test of exogeneity is a test of joint correlation between the error terms in the structural equation and those in the reduced-form equations for the endogenous variables. In the two-step estimator, the residuals from the first stage are included as regressors in the second stage. The Wald statistics is a test of significance of those residuals.

${ }^{22}$ Results for the Hansen-Sargan test are reported only for the OLS regressions. This is because econometric software do not allow to carry out such a test for the Tobit model. However, in order to have at least a feeling about the validity of the instruments used, the Tobit specifications have been estimated by OLS, so as to obtain the Hansen-Sargan statistic. The outcomes of the Hansen-Sargan test never rejected the null that the instruments were valid.
} 
the sample of cooperatives, the non-linear pattern followed by these variables is once again bell-shaped, showing that for the activity of non-cooperative firms some market power in the local credit market is beneficial, while it has negative effects after it goes beyond a threshold.

\section{[Insert table 4 here]}

To sum up the empirical evidence obtained, the results for the model of firm creation show a bellshaped relationship between bank market power and firm birth, for both cooperative and non-cooperative firms. This finding can be interpreted arguing that, at the time of their establishment, it is likely that firms are considered to be equally risky by banking institutions, independently of their legal structure. ${ }^{23}$ In other words, this seems to suggest that, when firms start-up, cooperatives' institutional characteristics would not represent for banks an element for discriminating between these firms and other business structures.

Passing to firms' activity rate, the results show that a relatively higher concentration of the credit market tends to favor non-cooperative firms, while this would be detrimental for cooperatives - which seem to benefit from a more intense banking competition. ${ }^{24}$ This conclusion appears to be coherent with the hypothesis put forward in the paper, according to which the effects produced by structure of the credit market can differ between coops and non-coops, due to the fact that cooperatives' institutional specificities can jeopardize the maintenance of lending relationships; so that, where the credit market is more concentrated, these firms would be disadvantaged.

On the other hand, the evidence according to which a greater banking competition would be beneficial for cooperatives could be explained by resorting to at least two arguments: firstly, a higher number of banks operating in the market could lead (the most) opaque firms to fractionalize their debt among several intermediaries, so as to maximize the amount of credit obtained. On their part, in such a situation, banks are more inclined to lend to opaque firms counting on the monitoring activity of the other intermediaries involved. This interpretation could be consistent with the multi-banks relationships phe-

\footnotetext{
${ }^{23}$ It is worth noting that in the sample of non-cooperative firms more than $90 \%$ observations lie below the threshold value of $\mathrm{HHI}$, while this figure is nearly $80 \%$ for cooperatives.

${ }^{24}$ For both cooperative and non-cooperative firms, almost $90 \%$ observations fall before the parabolas minimum and maximum points, respectively.
} 
nomenon (known as multiaffidamento) characterizing the Italian business practice (see for instance, $\mathrm{Pa}$ gano et al, 1998, and Ongena and Smith, 2000). An alternative interpretation could be that increased competitive pressures encourage more efficient bank screening procedures, so that banks are inclined to lend to (more) opaque firms on the basis of expected performance rather than past records. Indeed, as claimed by Benfratello et al. (2006, p. 9-10), as a consequence of higher competition, banks may "introduce better and more advanced practices in the screening, selection, evaluation and monitoring of projects and entrepreneurs. [...] These practices could include looking more carefully and with better tools at borrowers' future prospects, as opposed to relying purely on firms' marketable assets as collateral, which characterizes standard operating behavior in many cases".

The findings can be interpreted by means of the institutional complementarity approach à la Aoki (2001): the relationships between firms and banking institutions can be considered complementary in the sense that the presence of firms (i.e. their birth rate) and their effectiveness (evaluated in terms of their activity rate) are reinforced by the institutionalized presence of specific arrangements characterizing the governance mechanisms operating in the financial domain. More precisely, a relatively more concentrated banking system seems to be complementary to both the creation and activity of non-cooperative firms. On the other hand, while banks enjoying some market power appear to favor also the creation of cooperatives, it is a relatively more competitive banking system the institutional counterpart that strengthens cooperatives in their activity.

\subsection{Robustness}

To test the robustness of the results, several sensitivity checks are performed. Firstly, to account for market specific effects, the models are re-estimated by including market dummy variables. This specification is robust to the existence of market specific omitted variables; moreover, it reduces the concern for the endogeneity of the bank market power index. Results obtained from these estimations, presented in table 5, fully confirm the conclusions previously drawn.

[Insert table 5 here] 
As a further check, an alternative indicator of banking market structure is employed $(\Delta \mathrm{HHI})$. This is given by the absolute value of the change of $\mathrm{HHI}$ between the beginning and end of the period examined (Bonaccorsi di Patti and Dell'Ariccia, 2004). This is an inverse measure of bank market power, under the assumption that significant changes in industry structure affect banks' expectations of extracting future rents from borrowers. To make $\Delta \mathrm{HHI}$ positively correlated with market power, its linear transformation is taken (1- $\Delta \mathrm{HHI})$. Then, all regressions are re-run by including $1-\Delta \mathrm{HHI}$ and its squared (1- $\Delta \mathrm{HHI} 2)$. The results (not reported, but available from the author upon request) are basically unchanged.

Conclusions continue to hold also when sole traders are included in the sample of non-cooperative firms, and when the proxy used to measure the strength of community ties (STIES) is replaced with NOTIES - an inverse measure of social ties, given by the number of suicides normalized by population. Table 6 reports the marginal effects and threshold values of HHI for the estimates in tables 3, 4 and 5.

[Insert table 6 here]

\section{CONCLUSIONS}

This paper investigated the relationship between banking market structure and the creation and activity of firms. In order to test for differences among different business structures, the empirical analysis confronted cooperative and non-cooperative firms. The econometric investigation, carried out on a sample of Italian firms operating in 27 industries during the period 1998-2003, leads to some major conclusions. The first one is that the impact of bank market power on the creation of cooperatives does not seem to be different from that exerted on non-cooperative firms operating in the same local market. For all business types, the empirical analysis finds a bell-shaped relationship between bank market power and firms' birth rate, suggesting that firm creation is favored by a moderate bank market power, which is instead detrimental after it reaches a threshold. This finding - in line with the conclusions reached, for instance, by Petersen and Rajan (1995) and Zarutskie (2006) - can be interpreted arguing that, at the time of their establishment, firms tend to be considered equally risky by banking institutions. In other words, when firms start-up, cooperatives' institutional characteristics would not represent for banks an element for discriminating between these firms and other business types. 
A less homogeneous pattern, and this is a second main conclusion, is found with respect to firms' activity rate. In this regard, the empirical evidence still finds a bell-shaped parabola for non-cooperative firms. By contrast, a U-shaped relationship emerges for cooperatives: this seems to indicate that active cooperatives in the market benefit from more intense banking competition, even though it produces negative effects when too exasperated. This result lends support to the hypothesis put forward in the paper, according to which that the effects produced by the structure of the banking market can differ between coops and non-coops, since cooperatives' institutional specificities can jeopardize the possibility of maintaining lending relationships; so that, where the credit market is more concentrated, these firms would be disadvantaged. On the other hand, the evidence according to which a greater banking competition would be beneficial for cooperatives can be explained by resorting to at least two arguments: firstly, a higher number of banks operating in the market could lead (the most) opaque firms to fractionalize their debt among several intermediaries, in order to maximize the amount of credit obtained. On their part, in such a situation, banks are more inclined to lend to opaque firms counting on the monitoring activity of the other intermediaries involved (Pagano et al, 1998; Ongena and Smith, 2000). An alternative interpretation could be that increased competitive pressures encourage more efficient bank screening procedures, so that banks are inclined to lend to (more) opaque firms on the basis of expected performance rather than past records and firms' marketable assets as collateral (Benfratello et al. 2006).

In terms of the institutional complementarity approach, the findings suggest that, for the Italian case, a relatively more concentrated banking system is complementary to both the birth and activity of noncooperative firms. Moreover, while banks enjoying some market power tend to favor also the creation of cooperatives, it is a relatively more competitive banking system the institutional counterpart that strengthens their activity. Overall considered, the results for cooperatives are in line with the studies showing that the performance of these firms strongly depends on the institutional context in which they operate (e.g. Hovart, 1975; Gagliardi, 2009). A major implication of the evidence obtained is that, with regard to the creation phase of their life-cycle, cooperatives are not different from other firms - at least for how they tend to be perceived by banking institutions and respond to bank market power. It is, however, during their activity that cooperatives appear to manifest a behavior different from other enterprises and, in this respect, further research is called for to inquire into the sources and consequences of this diversity. 


\section{REFERENCES}

AGOSTINO M. and TRIVIERI F., 2008, 'Banking competition and SMEs bank financing. Evidence from the Italian provinces', Journal of Industry, Competition and Trade, 8, 1, 33-53.

AOKI M., 2001, Toward a Comparative Institutional Analysis, Cambridge, Massachusetts: MIT Press.

BARRO R., 1991, 'Economic growth in a cross section of countries', The Quarterly Journal of Economics, 106, 407-444.

BARTLETT W., CABLE G., ESTRIN S., JONES D.C. and SMITH S.C., 1992, 'Labour-managed cooperatives and private firms in North Central Italy: an empirical comparison', Industrial and Labour Relations Review, 46, $1,103-118$.

BENFRATELLO L., SCHIANTARELLI F. and SEMBENELLI A., 2006, 'Banks and innovation: microeconometric evidence on Italian firms', IZA Discussion Paper No. 2032.

BEN-NER A., 1988a, 'The life cycle of worker-owned firms in market economies: a theoretical analysis', Journal of Economic Behavior and Organization, 10, 287-313.

BEN-NER A., 1988b, 'Comparative empirical observations on worker-owned and capitalist firms', International Journal of Industrial Organisation, 6, 7-31.

BERTRAND M., SCHOAR A. and THESMAR D., 2007, 'Banking deregulation and industry structure: evidence from the French Banking reforms of 1985', The Journal of Finance, 62, 2, 597-628.

BLACK S.E. and STRAHAN P.E., 2002, 'Entrepreneurship and bank credit availability', The Journal of Finance, 6, 2807-2833.

BLAIR M., KRUSE D.L. and BLASI J.R., 2000, 'Employee ownership: an unstable form or a stabilizing force?', In M. Blair and T. Hockan (Eds.), The New Relationship: Human Capital in the American Corporation, Washington D.C: Brookings Institution Press.

BLANCHFLOWER D. and OSWALD A., 1990, 'What Makes an Entrepreneur?', Journal of Labor Economics, $16,26-60$.

BONACCORSI DI PATTI E. and DELL'ARICCIA G., 2004, 'Bank competition and firm creation', Journal of Money, Credit and Banking, 36, 2, 225-252.

BONIN J., JONES D.C. and PUTTERMAN L., 1993, 'Theoretical and empirical studies of producer cooperatives: will ever the twain meet?', Journal of Economic Literature, 31, 1290-1320.

BOOT A.W.A. and THAKOR A.V., 2000, 'Can relationship banking survive competition?', The Journal of Finance, 55, 2, 679-713.

CAO M. and SHI S., 2001, 'Screening, bidding, and the loan market tightness', European Finance Review, 5, 21-61.

CARBO' VALVERDE S., HUMPHREY D.B. and RODRIGUEZ F.R., 2003, 'Deregulation, bank competition and regional growth', Regional Studies, 37, 3, 227-237.

CETORELLI N., 1997, 'The role of credit market competition on lending strategies and on capital accumulation', Federal Reserve Bank of Chicago, Working Paper, 14.

CETORELLI N., 2001, 'Competition among banks: good or bad?', Economic Perspectives, 2, 38-48.

CETORELLI N., 2003, 'Life-cycle dynamics in industrial sectors: the role of banking market structure', The Federal Reserve Bank of St. Louis Review, 85, 4, 135-148.

CETORELLI N., 2004, 'Real effects of bank competition', Journal of Money, Credit and Banking, 36, 3, 543-558.

CETORELLI N. and PERETTO P., 2000, ‘Oligopoly banking and capital accumulation', Federal Reserve Bank of Chicago, Working Paper, 12. 
CETORELLI N. and STRAHAN P.E., 2006, 'Finance as a barrier to entry: bank competition and industry structure in local U.S. markets', The Journal of Finance, 61, 1, 437-461.

CHELL E., HAWORTH J. and BREARLEY S., 1991, The Entrepreneurial Personality, London: Routledge.

CHEN X., 2005, 'Financial liberalization, competition, and bank loan quality', Journal of Economic Integration, 20, 109-122.

CHEN X., 2007, 'Banking deregulation and credit risk. Evidence from the UE', Journal of Financial Stability, 2 , 356-390.

COOK M.L., 1995, 'The future of U.S. agricultural cooperatives: a neo-institutional approach', American Journal of Agricultural Economics, 77, 1153-1159.

DOW G., 2003, Governing the Firm, Cambridge: Cambridge University Press.

DRÈZE J., 1993, 'Self-management and economic theory', In P. Bardhan and J. Roemer (Eds.), Market Socialism: The Current Debate, Oxford: Oxford University Press.

ENBERG L., 1993, 'Financing employee-managed firms: some problems of a wider extension', Economic and Industrial Democracy, 14, 277-300.

ESTRIN S. and PEROTIN V., 1987, 'Producer Cooperatives: the British Experience', International Review of Applied Economics, 1, 2, 152-175.

EVANS D.S. and JOVANOVIC B., 1989, 'An estimated model of entrepreneurial choice under liquidity constraints', Journal of Political Economy, 97, 4, 808-827.

FAIRCLOUGH M., 1987, 'Mondragon in Context', Research Report n. 1, Dept. of Sociology, University of Bristol.

FORNI M. and PABA S., 2000, 'The source of local growth: evidence from Italy'. Giornale degli Economisti e Annali di Economia, 59, 1-49.

FOTOPOULOS G. and SPENCE N., 1999, 'Spatial variation in new manufacturing plant openings: some empirical evidence from Greece’, Regional Studies, 33, 219-229.

FURUBOTN E.G. and PEJOVICH S., 1970, 'Property rights and the behavior of the firm in a socialist state: the example of Yugoslavia', Zeitschrift für Nationalökonomie, 30, 5, 431-454.

GAGLIARDI F., 2009, 'Financial development and the growth of cooperative firms', Small Business Economics: An Entrepreneurship Journal, 32, 4, 439-464.

GAROFOLI G., 1994, 'New firm formation and regional development: the Italian case', Regional Studies, 28, 4, 381-393.

GUISO L., SAPIENZA P. and ZINGALES L., 2004a, 'Does local financial development matter?', The Quarterly Journal of Economics, 929-969.

GUISO L., SAPIENZA P. and ZINGALES L., 2004b, 'The role of social capital in financial development', The American Economic Review, 94, 3, 526-556.

GUZMAN M., 2000, 'Bank structure, capital accumulation and growth: a simple macroeconomic model', Economic Theory, 16, 421-455.

HELLIWELL J.F. and PUTNAM R., 1995, 'Economic growth and social capital in Italy', Eastern Economic Journal, 21, 295-307.

HOVART B., 1975, ‘An institutional model of a self-managed socialist economy', In B. Hovart, M. Markovic and R. Supek (Eds), Self-Governing Socialism, White Plains, NY: International Arts and Science Press.

JEFFERIS K. and MASON N., 1990. 'The financing of worker co-operatives in the UK. Evidence and implications', Annals of Public and Cooperative Economics, 61, 2-3, 213-244.

JOSSA B. and CUOMO G., 1997, The Economic Theory of Socialism and the Labour-Managed Firm. Market, Socialism and Labour Management, Cheltenham-Brookfield: Edward Elgar Publishers. 
KEEBLE D. and WALKER S., 1994, 'New firms, small firms and dead firms: spatial patterns and determinants in the United Kingdom', Regional Studies, 28, 411-427.

LEE S.Y., FLORIDA R. and ACS Z.J., 2004, Creativity and entrepreneurship: a regional analysis of new firm formation', Regional studies, 38, 8, 879-891.

LOGAN C. and GREGORY D., 1981, Co-operatives and Job Creation in Wales, Cardiff, Wales T.U.C.

MANKIW N.G., ROMER D. and WEIL D., 1992, 'A contribution to the empirics of economic growth', The Quarterly Journal of Economics, 107, 407-437.

MARQUEZ R., 2002, 'Competition, adverse selection, and information dispersion in the banking industry', Review of Financial Studies, 15, 901-926.

MILENKOVITCH D., 1971, Plan and Market in Yugoslav Economic Thought, New Haven: Yale University Press.

MYGIND N., 1990, 'The financing of self-managed firms in Denmark', Annals of Public and Cooperative Economics, 61, 2-3, 287-308.

OAKESHOTT R., 1978, The Case for Worker Co-ops. London: Routledge \& Kegan Paul.

ONGENA S. and SMITH D.C., 2000, 'What determines the number of bank relationships? Cross-country evidence', Journal of Financial Intermediation, 9, 1, 26-56.

PAGANO M., 1993, 'Financial markets and growth. An overview', European Economic Review, 37, 613- 622.

PAGANO M., PANETTA F. and ZINGALES L., 1998. 'Why do companies go public? An empirical analysis', Journal of Finance, 1, 27-64.

PANZAR J.C. and ROSSE J.N., 1987, 'Testing for monopoly equilibrium', The Journal of Industrial Economics, $35,4,443-56$.

PETERSEN M. and RAJAN R.G., 1995, 'The effect of credit market competition on lending relationships', The Quarterly Journal of Economics, 110, 407- 443.

PODIVINSKY J.A. and STEWART G., 2007, 'Why is labour-managed entry so rare? An analysis of UK manufacturing data', Journal of Economic Behavior and Organization, 63, 177-192.

PUTNAM R.D., 1993, Making Democracy Work. Civic Traditions in Modern Italy, Princeton NJ: Princeton University Press.

PUTTERMAN L., 1993, 'Ownership and the nature of the firm', Journal of Comparative Economics, 17, 2, $243-263$.

SCHLICHT E. and VON WEIZÄCKER C.C., 1977, Risk financing in labour-managed economies: the commitment problem, Zeitschrift für die gesamte staatswissenschaft, 133, 53-66.

SERVÈN L., 2003, 'Real exchange rate uncertainty and private investment in LDCs', Review of Economics and Statistics, 88, 1, 212-218.

SHAFFER S., 1998, 'The winner’s curse in banking', Journal of Financial Intermediation, 7, 359-92.

SMITH S.C., 2001, 'Blooming together or wilting alone? Network externalities and Mondragòn and La Lega cooperative networks', Discussion Paper n. 2001/27, World Institute for Development Economics Research, United Nations University.

STOREY D.J., 1982, Entrepreneurship and the New Firm, London: Croom Helm.

STRAHAN P.E., 2002, 'The real effects of U.S. banking deregulation', Federal Reserve Bank of St. Louis Review, $85,4,129-134$.

THOMAS A. and DEFOURNY J., 1990, 'Financing workers' co-operatives and self-managed enterprises', Annals of Public and Cooperative Economics, 61, 2-3, 167-174.

THOMAS H.T. and LOGAN C.,1982, Mondragon: An Economic Analysis, London: George Allen and Unwin. 
VANEK J., 1975, 'The basic theory of financing of participatory firms', In J. Vanek (Ed), The Labor Managed Economy, Ithaca, N.Y: Cornell University Press.

VITALIANO P., 1983, 'Cooperative enterprise: an alternative conceptual basis for analyzing a complex institution', American Journal of Agricultural Economics, 65, 5, 1078-1083.

WALL H.J., 2004, 'Entrepreneurship and the deregulation of banking', Economics Letters, 82, 333-339.

WOOLDRIDGE J.M., 2002, Econometric Analysis of Cross Section and Panel Data, Cambridge Massachusetts: MIT Press.

ZAMAGNI S., 2005, 'Per una teoria economico-civile dell'impresa cooperativa', In E. Mazzoli and S. Zamagni (Eds.), Verso una nuova teoria economica della cooperazione, Bologna: Il Mulino.

ZARUTSKIE R., 2006, 'Evidence on the effects of bank competition on firm borrowing and investment', Journal of Financial Economics, 81, 503-537 
TABLE 1 - Description of variables

\begin{tabular}{|c|c|}
\hline Variable & Description \\
\hline BIRTH_OF & Average birth rate of partnerships and corporations for the years 1999-2003 \\
\hline BIRTH_COOP & Average birth rate of cooperative firms for the years 1999-2003 \\
\hline ACTV_OF & Average activity rate of partnerships and corporations for the years 1999-2003 \\
\hline ACTV_COOP & Average activity rate of cooperative firms for the years 1999-2003 \\
\hline DEATH_OF & Average death rate of partnerships and corporations for the years 1999-2003 \\
\hline DEATH_COOP & Average death rate of cooperative firms for the years 1999-2003 \\
\hline INDUSHARE & Registered firms in industryi and province $p$ on total registered firms in the province in 1998 \\
\hline $\mathrm{HHI}$ & Average Herfindahl-Hirschman Index on deposits at provincial level for the period 1999-2003 (*100) \\
\hline $\mathrm{HHI} 2$ & Squared of the averageHerfindahl-Hirschman Index on deposits \\
\hline POP & Average provincial population for the period 1999-2003 \\
\hline EDUC & Share of workforce with a high school diploma or higher degree in 1997 \\
\hline STIES & Average electoral participation to the 1995 and 2001 referenda, and to the 1999 European elections \\
\hline CRIMEECO & Number of crimes committed against the economy normalized by population (average 1999-2003) *1000 \\
\hline CEN-NORTH & Dummy = 1 if firm is located in the Center Northern area and zero otherwise \\
\hline SOUTH & Dummy $=1$ if firm is located in the South and zero otherwise \\
\hline SMALLTOWN & Share of municipalities with less than 30,000 residents in 1996 \\
\hline ROADS & Kilometers of non-urban roads at the end of 1996 normalized by province area $\left(\mathrm{K}^{2}\right)$ \\
\hline RPI & Real per capita income in 1998 \\
\hline
\end{tabular}

All variables are drawn from InfoCamere except for: i) $\mathrm{HHI}$ and HHI2, obtained by calculations on data BILBANK (ABI) and Bank of Italy; ii) RPI, POP, STIES and CRIMEECO, drawn from ISTAT; iii) EDUC, SMALLTOWN and ROADS, drawn from Bonaccorsi di Patti et al . (2004).

TABLE 2 - Summary statistics

\begin{tabular}{|c|c|c|c|c|c|}
\hline Variable & Obs & Mean & Std.Dev. & Min & $\operatorname{Max}$ \\
\hline BIRTH_OF * & 2220 & 2.1657 & 2.2184 & 0 & 25.0 \\
\hline BIRTH_COOP* & 2220 & 2.0617 & 4.7024 & 0 & 50.0 \\
\hline ACTV_OF* & 2220 & 78.165 & 12.106 & 0 & 100 \\
\hline ACTV_COOP* & 2220 & 66.021 & 25.991 & 0 & 100 \\
\hline DEATH_OF ${ }^{*}$ & 2220 & 2.7468 & 1.4213 & 0 & 15.0 \\
\hline DEATH_COOP * & 2220 & 3.1506 & 5.3288 & 0 & 50.0 \\
\hline INDUSHARE * & 2220 & 4.4060 & 7.8410 & 0.0020 & 48.8177 \\
\hline $\mathrm{HHI}$ & 2220 & 13.177 & 5.525 & 5.15 & 42.45 \\
\hline $\mathrm{POP}^{+}$ & 2220 & 591,913 & 645,737 & 90,065 & $3,721,603$ \\
\hline EDUC * & 2220 & 37.207 & 4.099 & 22.406 & 49.460 \\
\hline STIES * & 2220 & 54.045 & 8.090 & 36.767 & 68.906 \\
\hline CRIMEECO & 2220 & 3.5993 & 1.3861 & 1.1218 & 11.7971 \\
\hline CEN-NORTH & 2220 & 0.6329 & 0.4821 & 0 & 1 \\
\hline SOUTH & 2220 & 0.3671 & 0.4821 & 0 & 1 \\
\hline SMALLTOWN * & 2220 & 48.519 & 25.650 & 0 & 93.330 \\
\hline ROADS * & 2220 & 17.986 & 3.545 & 7.800 & 26.300 \\
\hline $\mathrm{RPI}^{\#}$ & 2220 & 16.684 & 4.279 & 8.965 & 27.728 \\
\hline
\end{tabular}

For the description of the variables see table $1 .{ }^{*}$ In percentage terms; ${ }^{*}$ in thousands of Euro; ${ }^{+}$in units. All the other variables are dummies, with the exception of $\mathrm{HHI}$ and CRIMEECO (see table 1). 
TABLE 3 - Cooperative firms' birth and activity rates results

\begin{tabular}{|c|c|c|c|c|}
\hline & \multicolumn{4}{|c|}{ DEPENDENT VARIABLE } \\
\hline & \multicolumn{2}{|c|}{ BIRTH_COOP } & \multicolumn{2}{|c|}{ ACTV_COOP } \\
\hline & \multicolumn{2}{|c|}{ Interval regression } & \multicolumn{2}{|c|}{ Interval regression } \\
\hline BIRTH_OF & 1.0973 & 0.0000 & & \\
\hline DEATH_OF & 0.1659 & 0.3690 & & \\
\hline BIRTH_COOP & & & 0.1205 & 0.3480 \\
\hline DEATH_COOP & -0.0752 & 0.1490 & -0.6513 & 0.0000 \\
\hline ACTV_ŌF & & & 0.6633 & 0.0000 \\
\hline INDUSHARE & 0.0669 & 0.0210 & -0.1504 & 0.0680 \\
\hline $\mathrm{HHI}$ & 0.2732 & 0.0550 & -0.7503 & 0.0300 \\
\hline $\mathrm{HHI} 2$ & -0.9006 & 0.0100 & 2.1432 & 0.0060 \\
\hline POP & 1.3266 & 0.0000 & -1.0433 & 0.2600 \\
\hline EDUC & 0.0847 & 0.1500 & -0.0835 & 0.6230 \\
\hline STIES & 0.0254 & 0.6090 & -0.4088 & 0.0060 \\
\hline CRIMEECO & -0.1322 & 0.3920 & -0.1131 & 0.8160 \\
\hline CEN-NORTH & 0.5630 & 0.5870 & 2.9590 & 0.3130 \\
\hline ROADS & 0.0971 & 0.2660 & -0.0807 & 0.6710 \\
\hline SMALLTOWN & -0.0028 & 0.7600 & 0.0028 & 0.9130 \\
\hline $\mathrm{RPI}$ & 0.0156 & 0.8720 & 0.5715 & 0.0420 \\
\hline Wald test & 531.56 & 0.0000 & 862.56 & 0.0000 \\
\hline Wald test of exogeneity & 2.64 & 0.2676 & 3.61 & 0.1647 \\
\hline N.OBS & 2,220 & & 2,220 & \\
\hline left-censored & 1,204 & & 110 & \\
\hline uncensored & 1,016 & & 2,110 & \\
\hline
\end{tabular}

TABLE 4- Non-Cooperative firms' birth and activity rates results

\begin{tabular}{|c|c|c|c|c|}
\hline & \multicolumn{4}{|c|}{ DEPENDENT VARIABLE } \\
\hline & \multicolumn{2}{|c|}{ BIRTH_OF } & \multicolumn{2}{|c|}{ ACTV_OF } \\
\hline & \multicolumn{2}{|c|}{ Two-step Tobit } & \multicolumn{2}{|c|}{$2 S L S$} \\
\hline BIRTH_OF & & & -1.1410 & 0.0270 \\
\hline DEATH_OF & 0.1609 & 0.0030 & -1.2872 & 0.1430 \\
\hline INDUSHARE & 0.0176 & 0.3180 & 0.0343 & 0.9080 \\
\hline $\mathrm{HHI}$ & 0.9416 & 0.0630 & 24.907 & 0.0040 \\
\hline $\mathrm{HH} 2$ & -2.3917 & 0.0800 & -66.551 & 0.0040 \\
\hline POP & 0.0010 & 0.9950 & 2.9724 & 0.2660 \\
\hline EDUC & -0.0873 & 0.0180 & -2.5048 & 0.0000 \\
\hline STIES & -0.0230 & 0.1550 & -0.1436 & 0.5970 \\
\hline CRIMEECO & 0.0198 & 0.7940 & 2.6991 & 0.0330 \\
\hline CEN-NORTH & -0.6031 & 0.3860 & -26.406 & 0.0240 \\
\hline ROADS & -0.0867 & 0.2400 & -3.3365 & 0.0080 \\
\hline SMALLTOWN & -0.0070 & 0.1030 & 0.1429 & 0.0420 \\
\hline $\mathrm{RPI}$ & 0.1866 & 0.0030 & 2.5733 & 0.0180 \\
\hline Wald test & 831.58 & 0.0000 & & \\
\hline Wald test of exogeneity & 11.81 & 0.0027 & & \\
\hline F-test & & & 1.81 & 0.0017 \\
\hline Uncentered R-Squared & & & 0.703 & \\
\hline Sargan Statistic & & & 0.019 & 0.8903 \\
\hline Wu-Hausman test & & & 86.09 & 0.0000 \\
\hline Durbin-Wu-Hausman test & & & 162.64 & 0.0000 \\
\hline N.OBS & 2,220 & & 2,220 & \\
\hline left-censored & 222 & & & \\
\hline uncensored & 1,998 & & & \\
\hline
\end{tabular}

For the description of the variables see table 1 . The regressions are estimated employing market-industry observations. In italics are reported the $\mathrm{p}$-values of the tests. The $\mathrm{z}$ and $\mathrm{t}$ statistics (not reported) are based on robust standard errors. In both tables, industry dummies and constant included but not reported. Interval regression is a Tobit estimation with robust SE. The instrumental variables used in the regressions testing for endogeneity are: the 1995 value of HHI; DENSITY (provincial population over province area), and MUN (number of municipalities at provincial level in logarithm terms). 
TABLE 5 - Robustness: including market fixed effects

DEPENDENT VARIABLE

BIRTH_COOP BIRTH_OF $\quad$ ACTV_COOP $\quad$ ACTV_OF

\begin{tabular}{|c|c|c|c|c|c|c|c|c|}
\hline & \multicolumn{2}{|c|}{ Interval regression } & \multicolumn{2}{|c|}{ Interval regression } & \multicolumn{2}{|c|}{ Interval regression } & \multicolumn{2}{|c|}{ Linear regression } \\
\hline BIRTH_OF & 0.2496 & 0.0410 & & & & & -0.1964 & 0.2780 \\
\hline DEATH_OF & -0.0299 & 0.8690 & 0.0722 & 0.2850 & & & 0.3167 & 0.3180 \\
\hline BIRTH_COOP & & & & & -0.0067 & 0.9600 & & \\
\hline DEATH_COOP & -0.0769 & 0.1550 & & & -0.6888 & 0.0000 & & \\
\hline ACTV_OF & & & & & 0.1976 & 0.0640 & & \\
\hline INDUSHARE & 0.0668 & 0.0390 & 0.0116 & 0.3240 & -0.1377 & 0.0620 & -0.0138 & 0.7010 \\
\hline $\mathrm{HHI}$ & 0.6712 & 0.0360 & 0.1222 & 0.0300 & -2.2365 & 0.0020 & 1.1159 & 0.0000 \\
\hline $\mathrm{HHI} 2$ & -1.4592 & 0.0370 & -0.2320 & 0.0570 & 4.8961 & 0.0010 & -2.0514 & 0.0000 \\
\hline POP & 1.5763 & 0.0310 & -0.0840 & 0.4860 & -6.8612 & 0.0020 & -2.5538 & 0.0000 \\
\hline EDUC & 0.1352 & 0.4430 & -0.0776 & 0.0170 & 0.4408 & 0.2580 & -0.8592 & 0.0000 \\
\hline STIES & 0.0033 & 0.9710 & 0.0471 & 0.0140 & -0.6469 & 0.0480 & -0.2816 & 0.0010 \\
\hline CRIMEECO & -0.2230 & 0.5330 & -0.1187 & 0.1310 & -2.8514 & 0.0010 & -1.1950 & 0.0000 \\
\hline ROADS & -0.0048 & 0.9840 & 0.0492 & 0.3930 & 0.0902 & 0.8520 & 0.4496 & 0.0210 \\
\hline SMALLTOWN & 0.0221 & 0.2670 & -0.0010 & 0.7790 & 0.0546 & 0.4010 & -0.0083 & 0.7030 \\
\hline RPI & 0.4928 & 0.0160 & 0.0115 & 0.7790 & 2.0229 & 0.0000 & 0.4987 & 0.0030 \\
\hline F-test & & & & & & & 51.37 & 0.0000 \\
\hline R-Squared & & & & & & & 0.6774 & \\
\hline Wald test & 716.91 & 0.0000 & 3117.37 & 0.0000 & 1914.68 & 0.0000 & & \\
\hline N.OBS & 2,220 & & 2,220 & & 2,220 & & 2,220 & \\
\hline left-censored & 1,204 & & 222 & & 110 & & & \\
\hline uncensored & 1,016 & & 1,998 & & 2,110 & & & \\
\hline
\end{tabular}

For the description of the variables see table 1 . The regressions are estimated employing market-industry observations. In italics are reported the $p$-values of the tests. The $z$ and $t$ statistics (not reported) are based on robust standard errors. Industry dummies, market dummies and constant included but not reported. 
TABLE 6 - Marginal effects and threshold values for firms' birth and activity rates

\begin{tabular}{|c|c|c|c|c|}
\hline \multicolumn{5}{|l|}{$A$ - Industry fixed effects } \\
\hline & \multicolumn{4}{|c|}{ DEPENDENT VARIABLE } \\
\hline & BIRTH_COOP & BIRTH_OF & $\begin{array}{l}\text { ACTV }_{-} \\
\text {COOP }\end{array}$ & ACTV_OF \\
\hline BIRTH_OF & 0.3195 & & & -1.1410 \\
\hline DEATH_OF & 0.0483 & 0.1290 & & -1.2872 \\
\hline BIRTH_COOP & & & 0.0871 & \\
\hline DEATH_COOP & -0.0219 & & -0.4707 & \\
\hline ACTV_ŌF & & & 0.4795 & \\
\hline INDUSHARE & 0.0195 & 0.0094 & -0.1087 & 0.0343 \\
\hline $\mathrm{HHI}$ & 0.0796 & 0.0386 & -0.5424 & 24.907 \\
\hline $\mathrm{HHI} 2$ & -0.2623 & -0.0830 & 1.5491 & -66.551 \\
\hline POP & 0.3863 & -0.1882 & -0.7541 & 2.9724 \\
\hline EDUC & 0.0247 & -0.0158 & -0.0604 & -2.5048 \\
\hline STIES & 0.0074 & -0.0072 & -0.2955 & -0.1436 \\
\hline CRIMEECO & -0.0385 & -0.0370 & -0.0818 & 2.6991 \\
\hline CEN-NORTH & 0.1629 & 0.1760 & 2.1483 & -26.406 \\
\hline ROADS & 0.0283 & 0.0024 & -0.0584 & -3.3365 \\
\hline SMALLTOWN & -0.0008 & -0.0067 & 0.0020 & 0.1429 \\
\hline $\mathrm{RPI}$ & 0.0045 & 0.0556 & 0.4131 & 2.5733 \\
\hline Threshold value of $\mathrm{HHI}$ & 0.1517 & 0.2327 & 0.1750 & 0.1871 \\
\hline
\end{tabular}

$B$ - Industry and market fixed effects

\begin{tabular}{lcccc}
\hline \multicolumn{4}{c}{ DEPENDENT VARIABLE } \\
& BIRTH_COOP & BIRTH_OF & $\begin{array}{c}\text { ACTV_ } \\
\text { COOP }\end{array}$ & ACTV_OF \\
\hline BIRTH_OF & 0.0720 & & & -0.1964 \\
DEATH_OF & -0.0086 & 0.0504 & & 0.3167 \\
BIRTH_COOP & & & -0.0051 & \\
DEATH_COOP & -0.0222 & & -0.5202 & \\
ACTV_OF & & & 0.1493 & -0.0138 \\
INDUSHARE & 0.0193 & 0.0081 & -0.1040 & 1.1159 \\
HHI & 0.1937 & 0.0854 & -1.6892 & -2.0514 \\
HHI2 & -0.4210 & -0.1620 & 3.6979 & -2.5538 \\
POP & 0.4548 & -0.0587 & -5.1821 & -0.8592 \\
EDUC & 0.0390 & -0.0542 & 0.3329 & -0.2816 \\
STIES & 0.0009 & 0.0329 & -0.4886 & -1.1950 \\
CRIMEECO & -0.0643 & -0.0829 & -2.1536 & 0.4496 \\
ROADS & -0.0014 & 0.0343 & 0.0682 & -0.0083 \\
SMALLTOWN & 0.0064 & -0.0007 & 0.0413 & 0.4987 \\
RPI & 0.1422 & 0.0080 & 1.5278 & \\
& & & & \\
Threshold value of HHI & 0.2300 & 0.2635 & 0.2284 & 0.2720 \\
& & & &
\end{tabular}

For the description of the variables see table 1. In the models for BIRTH_OF, BIRTH_COOP and ACTV_COOP the interpretation of the marginal effects is in terms of the impact of a change in the independent variables on the expected value of BIRTH and ACTV, conditional on being uncensored. The standard interpretation applies to the model for ACTV_OF. In all models $d y / d x$ is for discrete change of dummy variable from 0 to 1. 
BIRTH_OF

BIRTH_COOP 0.2823

DEATH_COOP

ACTV_OF

ACTV_COOP

HHI2

$\mathrm{HHI} 2$

POP

EDUC

CRIMEECO

0.2823

0.1643

0.0787

1
0.0469

$-0.0046$

$-0.0076$

1
0.0556

0.0289

0.0557

0.0391

0.0289

$\begin{array}{ll}-0.0495 & 0.0370 \\ -0.0395 & -0.1225\end{array}$

$\begin{array}{lll}-0.0142 & -0.0395 & -0.1225 \\ -0.0234 & -0.0514 & -0.1309\end{array}$

$\begin{array}{lll}-0.0142 & -0.0395 & -0.1225 \\ -0.0810 & -0.0514 & -0.1309 \\ -0.0584 & 0.0206 & 0.0179\end{array}$

$-0.0584-0.0483-0.0199$

CEN_NORTH

0.0483

0.0199

$\begin{array}{ll}-0.0233 & 0.0137\end{array}$

RAODS

$-0.0233$

$-0.0305$

RPI

0.1747

$-0.0085$

0.0499

0.015
-0.133
0.027
-0.106
-0.095
-0.0213
-0.0192
0.1268
-0.0323
0.1120
0.025
0.0191
0.13

$\begin{array}{cc}1 & \\ 0.3503 & 1 \\ 0.1220 & -0.0152 \\ 0.1073 & 0.0786 \\ 0.1047 & 0.0910 \\ -0.2812 & -0.1037 \\ -0.2934 & -0.1204 \\ 0.2095 & 0.0551 \\ -0.1263 & -0.0342 \\ 0.1873 & 0.0815 \\ 0.1472 & 0.0857 \\ -0.1919 & -0.1008 \\ 0.1741 & 0.0825\end{array}$

1
0.0108
0.0088
-0.0345
-0.0055
0.0224
-0.0034
0.0246
0.0239
-0.005
0.0188

1

$0.9586 \quad 1$

$\begin{array}{rrr}-0.2761 & -0.2061 & 1 \\ 0.0118 & -0.0679 & 0.108\end{array}$

$\begin{array}{llll}0.01864 & -0.0679 & 0.1080 & 1\end{array}$

$\begin{array}{lllll}0.0873 & 0.0567 & -0.0310 & -0.0911 & 1\end{array}$

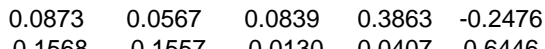

\begin{tabular}{lllllll}
-0.1568 & -0.1557 & -0.0130 & 0.0407 & 0.6446 & -0.0921 \\
\hline & 0.2638 & 0.2435 & -0.3220 & -0.0642 & 0.0422 & 0.1956
\end{tabular}

$\begin{array}{lllll}0.2638 & 0.2435 & -0.3220 & -0.0642 & 0.0422 \\ -0.1284 & -0.1829 & 0.0030 & 0.3944 & -0.4027\end{array}$

$\begin{array}{lllll}-0.1284 & -0.1829 & 0.0030 & 0.3944 & -0.4027 \\ -0.2290 & -0.1850 & 0.1753 & -0.1489 & 0.6313\end{array}$

1
0.1824
-0.3999

-0.3999
0.6628

0.016

0.0164

$-0.413 \quad 1$
For the description of the variables see table 1 . 